PoETRY

Published April 26, 2021

\title{
LIFE AS HAIKU
}

Life is no haiku

And I would tell you why not

If I had the time

To

\section{CORRESPONDING AUTHOR}

Daniel C. Douek

\section{ABOUT THE AUTHOR}

Daniel C. Douek's pastimes are making bread, growing vegetables in winter and immunology.

One of these is also his job.

DOI

10.20411/pai.v6i1.442

\section{FOOTNOTES}

Submitted April 16, 2021 | Accepted April 18, 2021 | Published April 26, 2021

\section{COPYRIGHT}

Copyright (C) 2021 Pathogens and Immunity

This is an open-access article distributed under the terms of the Creative Commons Attribution 4.0 International License. 